Original Research Paper

\title{
Performance, Carcass Traits and Quality of Longissimus lumborum muscle of Santa Inês lambs
}

\author{
${ }^{1}$ Fabio Borba Ferrari ${ }^{*},{ }^{1}$ Juliana Lolli Malagoli de Mello, ${ }^{1}$ Rodrigo Fortunato de Oliveira, ${ }^{3}$ Rondineli Pavezzi \\ Barbero, ${ }^{1,2}$ Rodrigo Alves de Souza, ${ }^{2}$ Viviane Borba Ferrari, ${ }^{1}$ Aline Giampietro-Ganeco, ${ }^{1}$ Diego Marcel \\ Ogoshi Coró, ${ }^{4}$ Wilton Ladeira da Silva, ${ }^{1}$ Pedro Alves de Souza and ${ }^{1}$ Hirasilva Borba \\ ${ }^{I}$ Department of Technology, São Paulo State University-UNESP, Jaboticabal, São Paulo, Brazil \\ ${ }^{2}$ School of Animal Science and Food Engineering, University of São Paulo-USP, Pirassununga, São Paulo, Brazil \\ ${ }^{3}$ Institute of Animal Science, Department of Animal Production, \\ Federal University of Rio de Janeiro (UFRRJ), Rio de Janeiro, Brazil \\ ${ }^{4}$ Federal University of Goiás, Goiânia, Brazil
}

Article history

Received: 12-09-2019

Revised: $10-12-2019$

Accepted: 08-01-2020

Corresponding Author: Fabio Borba Ferrari

Department of Technology,

São Paulo State University-

UNESP, Jaboticabal, São

Paulo, Brazil

Email: fbf zoo@hotmail.com

\begin{abstract}
The aim of this research was to evaluate carcass traits and meat quality of finishing lambs in pastures with different leaf area index with or without high protein-mineral supplementation. In this study, forty-eight young Santa Inês rams were used, with an average initial body weight of $13.5 \mathrm{~kg}$ and an average age of 4 months. For approximately $10 \mathrm{~h}$ a day, the animals had access to pastures comprised of Cynodon spp cultivar Tifton 85. In vivo measurements, including body length, anterior and posterior heights, chest perimeter, rump and thoracic widths, were evaluated. Based on the data in this study, providing supplements for sheep improved the carcass composition as increased hot carcass weight, cold carcass weight, empty body weight, carcass yield, external and internal carcass lengths and thoracic depth. Moreover, supplementation increased slaughter weight, which accounts for the largest portion of the producer's profitability. Although the use of supplements increases production costs, it also improved quantitative and qualitative characteristics of the meat, which could satisfy the consumer market. The meat from supplemented animals had a lower atherogenicity index compared to the control suggesting the meat from supplemented lambs is healthier to be consumed.
\end{abstract}

Keywords: Atherogenicity Index, Carcass Yield, Supplementation, Thoracic Depth, Total Cholesterol

\section{Introduction}

The largest share of sheep meat consumers looks for a product derived from young animals, five to six months of age, with carcasses weighing from 13 to 15 $\mathrm{kg}$. A high proportion of muscle and uniform fat coverage is desired which is obtained from the slaughter of animals with 30 to $35 \mathrm{~kg}$ body weight (Lage, 2009).

Because of its high-speed growth, the lamb is the animal model that has the greatest production efficiency, resulting in improved carcass dressing and meat quality (Pires et al., 2000). This model, generally associated with feedlot systems, allows maximum weight gain potential during the young age phase. However, the finish lambs utilizing a feedlot can sometimes be a less economical practice because of feed prices, which can represent about $70 \%$ of total production costs (Barros,
2013). Therefore, finishing sheep on pasture, combined with the use of multiple supplements, provides satisfactory body weight gains with lower costs.

Pasture management, associated with supplementation strategies, increases animal performance and can reduce the slaughter age, producing younger animals with more desirable meat characteristics.

Grazing time and ingestion rate influence forage intake by grazing animals, which varies depending on the bite size and the bite rate. These two variables are highly correlated with the canopy structure. Larger canopy structure negatively affects intake by the animals, due to the lower availability of leaves in the upper layers. This also decreases bite size due to the increased difficulty of gripping forages with longer stems. Forage intake can also be affected by canopy density, both by vertical and horizontal distribution, as
Science

Publications
(C) 2020 Fabio Borba Ferrari, Juliana Lolli Malagoli de Mello, Rodrigo Fortunato de Oliveira, Rondineli Pavezzi Barbero, Rodrigo Alves de Souza, Viviane Borba Ferrari, Aline Giampietro-Ganeco, Diego Marcel Ogoshi Coró, Wilton Ladeira da Silva, Pedro Alves de Souza and Hirasilva Borba. This open access article is distributed under a Creative Commons 
well as by tiller and leaf population density. Forage intake is negatively affected by lower population density of tillers, which directly compromises the size of the bite and is not compensated by an increase in bite rate, therefore reducing intake (Ungar and Noy-Meir, 1988). The individual size of the tillers also negatively affects the bite size, due to the higher proportion of support tissues that the animals avoid while grazing (Flores et al., 1993). Additionally, low leaf density also negatively affects bite size due to the low bite depth (Laca et al., 1992).

The finishing of lambs in Tifton 85 pastures, supplemented with concentrate up to $2 \%$ of the body weight on a dry matter basis, improved productive performance and carcass characteristics, providing greater slaughter and warm carcass weights of Santa Inês lambs, as supplementation increased (Carvalho et al., 2007).

Disease, genetics, gender, age, innervation, location, type of muscle, exercise and diet can influence the nature of muscle fibers (Stockdale, 1992; Ono et al., 1993; Macedo et al., 2000; Vestergaard et al., 2000). The pH, color, tenderness and water holding capacity can improve the quality of housing, according to the proportion between the types of muscle fibers (Klont et al., 1998). These factors have more influence in muscle transformation post mortem, suggesting the importance in this study of characteristics and types of muscle fibers in the meat of sheep (Sazili et al., 2005).

Thus, the objective of this research was to evaluate how supplementation and the residual leaf area index can modify or improve the carcass traits and meat quality of lambs.

\section{Materials and Methods}

\section{Experimental Area}

Animals were reared and harvested from October 2011 to March 2012 in the Forage Sector at São Paulo State University - FCAV/UNESP, Campus Jaboticabal, São Paulo, Brazil. The physical and chemical analyses were performed at São Paulo State University at the Laboratory of Technology of Animal Products and the classification of Longissimus lumborum muscle fibers were conducted at the Laboratory of Histology and Embryology, Department of Animal Morphology. The Ethics Committee for the Use of Animals from São Paulo State University (Jaboticabal, São Paulo, Brazil) approved and reviewed the trial by protocol number 004633/13.

\section{Animals and Treatments}

The trial was performed using forty-eight, 120 day old, uncastrated, Santa Inês rams, with an initial body weight of $15 \mathrm{~kg}$. Thirty-two pastures were used $\left(100 \mathrm{~m}^{2}\right)$ which were enclosed and divided by a fence a $1.20 \mathrm{~m}$ tall electric fence $(5.000 \mathrm{v})$ with four strands of wire. To protect the animals in the hottest hours of the day mobile shades were placed in the pastures. From 6:00 am to
4:00 pm, all the animals remained in 32 pastures with Tifton-85 (Cynodon spp.), with different residual leaf area index. The pasture management utilized was rotational stocking. The regrowth period varied according to canopy Light Interception (LI). To achieve the desired residual leaf area index (rLAI) over four grazing days, some regulator animals were added.

The chemical composition of Tifton-85 pastures, expressed on a dry matter basis, is presented in Table 1 .

The four grazing intensity treatments consisted of rLAI of $0.8,1.4,2.0$ and 2.6. The animals were transferred to the pasture when 95\% Light Interception (LI) had been reached during the resting period and the defined rLAI was observed. The rLAI was measured daily on each pasture.

The analyzer equipment, AccuPAR LP-80 (Decagon Devices, Inc., Pullman, WA, USA) consisting of a bar with light sensors that capture the radiation (at a frequency of 400-700 nm) either above the canopy or on the ground level, was used to determine LAI and the LI. The LI monitoring of the canopy was carried out at the time of removal of the animals from pastures and during the pasture regrowth. The LI measurements were performed weekly until the LI value was close to $95 \%$ and then on a daily basis until LI reached $95 \%$. The LAI was monitored daily at the time of entry for animals in pastures (pre-grazing) and during grazing. As rLAI was reached the animals were led to another pasture that had reached the LI target of $95 \%$ of during the rest period.

The supplemented animals (24 animals) were kept in individual stalls, receiving $0.7 \%$ of body weight of a high protein-energy supplement (Table 2), after 4:00 pm.

The animals were weighed weekly and the color of the conjunctiva of the eye mucosa was monitored by the Famacha ${ }^{\circledR}$ method (Molento et al., 2004).

The twenty-four supplemented animals were allocated to sixteen pastures with different residual leaf area index $(0.8,1.4,2.0$ and 2.6) and the other twentyfour animals from the control group were allocated with the same conditions. There were four pastures per treatment with six animals per pasture. In this trial, the treatments were a cross factorial between $\operatorname{rLAI}(0.8,1.4,2.0$ and 2.6) and supplemented or not, totalizing 8 treatments. The slaughter criteria was the age of the animals.

The chemical composition analyzes were performed according to (AOAC, 1990) based on the dry matter as Crude Protein (CP), Neutral Detergent Fiber (NDF) and acid detergent fiber (ADF; Senger et al., 2008) and Lignin (LIG; Silva and Queiroz, 2002). The In Vitro Dry Matter Digestibility (IVDMD) was determined using the method described by (Tilley and Terry, 1963) adapted by (Holden, 1999).

Table 3 presents the total forage mass, morphological components, chemical composition and in vitro dry matter digestibility, in pre-and post-grazing of Tifton 85 grasslands managed under four rLAI. 


\section{Slaughter, in Vivo and Carcass Traits}

The animals were weighed after being fasted for $16 \mathrm{~h}$. Prior to slaughter, the lambs were weighed again to obtain Final Body Weight (FBW) and the biometric measurements were carried out with the animals standing on a flat surface. The Body length (distance between the cervico-thoracic joint and the base of the tail), anterior height (distance between the withers and the distal end of the forelimb), posterior height (distance between the sacral tuberosity and distal end of the hindlimb), chest perimeter (perimeter based on the sternum and withers, passing the tape behind the shoulder), rump width (maximum distance between the trochanter of the femur), chest width (distance between the side faces of the scapularhumeral joint) and body compactness (body weight at slaughter divided by the body length of the animal).

After fasting, weighing and measurements, the animals were electrically stunned $(220 \mathrm{~V}$ for $8 \mathrm{sec})$ and bled according to the humane slaughter procedures (Monteiro et al., 2000). The carcasses were divided longitudinally and the left half-carcass sectioned in five anatomical regions: neck, shoulder, rib, loin and leg to obtain yield of cuts relative to the half-carcass weight, (Colomer-Rocher et al., 1998).

\section{Qualitative Muscle Traits}

The color traits were determined using a portable Minolta CR-400 colorimeter (Konica Minolta Sensing Inc., Osaka, Japan; diffuse illumination $/ 0^{\circ}$ angle of viewing, illuminant D65). The measures were performed in three different positions of the longissimus lumborum muscle after deboning. This device gauges the changes of lightness $\left(\mathrm{L}^{*}\right)$, intensity of red $\left(\mathrm{a}^{*}\right)$ and yellow $\left(\mathrm{b}^{*}\right)$, according to CIELab scale. Three measures were made in different places of the surface.

The fat color was taken at one point on the external fat coverage of the ribeye region located in the portion between the 11th and 12th ribs.

The meat $\mathrm{pH}$ was determined in triplicate using a digital $\mathrm{pH}$ meter (Testo ${ }^{\circledR}$ brand, model 230, Testo Inc., Sparta, NJ, USA), equipped with a glass penetration electrode for direct measurement from within the samples. The final $\mathrm{pH}$ value was considered as the average of all measures taken in the sample.

The Water Holding Capacity (WHC) was determined by the method proposed by (Hamm, 1977). The cooking loss was determined by the method proposed by (Wheeler et al., 1990). The Shear Force (SF) was determined by the method proposed by (Wheeler et al., 1990), using a texturometer (Texture Analyzer TA, XT2i) coupled to a Warner-Bratzler blade that was $1.016 \mathrm{~mm}$ thick. The results were expressed in Newton (N). Analyses of chemical composition comprising protein, ether extract, moisture and ash were performed according to (AOAC, 1995).
The total collagen was quantified by determining the amino acid hydroxyproline according to the methodology proposed by (AOAC, 1995).

\section{Muscle Fibre Structure Analysis}

The identification of fiber types was determined by the method proposed by (Dubowitz and Brooke, 1973).

The classification of muscle fibers was obtained by the techniques and it was possible to distinguish three types of muscle fibers and rank them by Slow Oxidative (SO), Fast Oxidative Glycolytic (FOG) and Fast Glycolytic (FG) using the color as a parameter, shown in Table 4.

\section{Statistical Analysis}

Data were analyzed by analysis of variance, using the Mixed procedure of SAS (2002), with statistical models that included the fixed effects of Leaf Area Index (LAI) $(0.8 ; 1.4 ; 2.0 ; 2.8)$ and supplemented or not (zero and $0.7 \%$ ). For significant effects, the means were compared using a Tukey test at 5\% significance.

Table 1: Mean chemical composition of Cynodon dactylon cultivar Tifton-85

\begin{tabular}{lc}
\hline Nutrients & $\%$ \\
\hline CP & 09.2 \\
DM & 93.0 \\
FAT & 01.4 \\
NDF & 66.4 \\
ADF & 37.2 \\
TDN & 61.0 \\
ASH & 06.1 \\
\hline
\end{tabular}

CP-crude protein; DM-dry matter; FAT-fat; NDF-neutral detergent fiber; ADF-acid detergent fiber; TDN-total digestible nutrients; ASH-ash

Table 2: Composition of commercial supplement offered to grazing finishing lambs

\begin{tabular}{lr}
\hline Product guarantee levels & $\%$ \\
\hline Crude Protein & 18.0 \\
NNP-Equal protein & 8.0 \\
Fat & 0.1 \\
TND & 70.0 \\
Fibrous Matter & 18.0 \\
Mineral Matter & 19.0 \\
Moisture & 12.0 \\
Calcium & 2.0 \\
Phosphor & 0.4 \\
mg/kg & \\
Sodium & 4.500 \\
Sulfur & 3.300 \\
Copper & 16.000 \\
Manganese & 47.000 \\
Zinc & 61.000 \\
Iodine & 1.200 \\
Cobalt & 1.000 \\
Selenium & 0.300 \\
Monensin & 45.000 \\
\hline
\end{tabular}


Table 3: Total forage mass, morphological components, chemical composition and In Vitro Dry Matter Digestibility (IVDMD), in pre- and post-grazing pastures of Tifton 85 grasslands managed under four residual Leaf Area Index (rLAI)

\begin{tabular}{|c|c|c|c|c|c|c|c|c|c|c|c|}
\hline \multicolumn{4}{|c|}{ Pre-grazing } & \multicolumn{4}{|c|}{ Post-grazing } & \multicolumn{4}{|c|}{ Chemical Composition } \\
\hline TDM & & & & TDM & & & & $\mathrm{CP}(\%)$ & & & \\
\hline rLAI 0.8 & rLAI 1.4 & rLAI 2.0 & rLAI 2.6 & rLAI 0.8 & rLAI 1.4 & rLAI 2.0 & rLAI 2.6 & rLAI 0.8 & rLAI 1.4 & rLAI 2.0 & rLAI 2.6 \\
\hline 6504 & 6093 & 6366 & 7238 & 3255 & 3989 & 4783 & 5402 & 17.51 & 18.48 & 17.45 & 17.28 \\
\hline DML & & & & DML & & & & $\mathrm{NDF}(\%)+\mathrm{AD}$ & $\mathrm{F}(\%)$ & & \\
\hline rLAI 0.8 & rLAI 1.4 & rLAI 2.0 & rLAI 2.6 & rLAI 0.8 & rLAI 1.4 & rLAI 2.0 & rLAI 2.6 & rLAI 0.8 & rLAI 1.4 & rLAI 2.0 & rLAI 2.6 \\
\hline 1800 & 1606 & 1609 & 1762 & 242 & 304 & 393 & 460 & $75.04+32.20$ & $74.26+32.14$ & $74.07+32.30$ & $74.16+33.13$ \\
\hline DMS & & & & DMS & & & & LIG(\%) & & & \\
\hline rLAI 0.8 & rLAI 1.4 & rLAI 2.0 & rLAI 2.6 & rLAI 0.8 & rLAI 1.4 & rLAI 2.0 & rLAI 2.6 & rLAI 0.8 & rLAI 1.4 & rLAI 2.0 & rLAI 2.6 \\
\hline 2575 & 2674 & 2791 & 3047 & 1563 & 2038 & 2512 & 2524 & 4.98 & 4.32 & 4.35 & 4.32 \\
\hline DMDM & & & & DMDM & & & & IVDMD (\%) & & & \\
\hline rLAI 0.8 & rLAI 1.4 & rLAI 2.0 & rLAI 2.6 & rLAI 0.8 & rLAI 1.4 & rLAI 2.0 & rLAI 2.6 & rLAI 0.8 & rLAI 1.4 & rLAI 2.0 & rLAI 2.6 \\
\hline 1543 & 1638 & 1901 & 2369 & 1010 & 1226 & 1651 & 1810 & 65.12 & 65.34 & 64.28 & 65.14 \\
\hline
\end{tabular}

TDM = Total Dry Mass; DML = Dry Mass of Leaves; DMS = Dry Mass of Stalks; DMDM = Dry Mass of Dead Material; CP $=$ Crude Protein; NDF+ADF = Neutral Detergent Fiber + Acid Detergent Fiber; LIG = Lignin; IVDMD = in vitro Dry Matter Digestibility

Table 4: Classification of Longissimus lumborum muscle fibers of lambs on pasture with different LAI, supplemented or not, as staining NADH-TR and immunohistochemistry

\begin{tabular}{|c|c|c|c|c|}
\hline \multirow[b]{2}{*}{ Classification } & \multicolumn{2}{|l|}{ Feature } & \multicolumn{2}{|l|}{ Technique } \\
\hline & Contraction & Metabolism & NADH-TR & Imuno \\
\hline$\overline{\mathrm{SO}}$ & Slow & Oxidative & +++ & ++ \\
\hline FOG & Fast & Oxidative-Glycolytic & ++ & - \\
\hline FG & Fast & Glycolytic & + & - \\
\hline
\end{tabular}

NADH-TR: +++ (dark purple); ++ (purple); + (light purple); Imuno: ++ (golden); - (no reaction)

\section{Results and Discussion}

Tables 5 and 6 present the in vivo characteristics and lamb carcass measurements finished at different leaf area index LAI, with or without supplementation.

There was no significant effect $(p \geq 0.05)$ of LAI on the quantitative in vivo characteristics. However, supplementation increased EBW, chest circumference and width compared to the control group $(p \leq 0.05)$. The EBW were 22.65 and $18.53 \mathrm{~kg}$, for the supplemented and control group animals, respectively. These results can be explained by greater daily energy intake in the diet of the supplemented lambs, compared to those kept in pasture without supplementation, providing greater weight gain and final slaughter weight (Carvalho et al., 2007). In this study, the supplemented animals consumed about $7 \%$ more TDN (Total Digestible Nutrients) than the control group, contributing to improved performance of supplemented animals.

Despite the additional costs, supplementation is one of the alternatives to improve production indices, which ensures the animal better physiological conditions to combat the adversities that may occur during animal production, thus contributing to obtaining younger animals for slaughter. This fact, can be explained by the trial performed by (Silva, 2014). In this trial, the authors observed $9.5 \%$ increase in daily average gain, $21 \%$ in average gain per area. Thus, the supplementation is a strategic way to increase the profitability of the property and shorten the production cycle with low investment.

Evaluating the effects of supplementation, it was observed that the supplemented animals had greater hot carcass weight, cold carcass weight and empty body weight compared to control group animals $(p<0.05)$. There was no effect of LAI on quantitative carcass characteristics. The greater carcass weight can be considered as a consequence of the greater slaughter weight and the empty body weight due to the lower amount of gastrointestinal content. According to (Martinez et al., 2001), carcass dressing depends mainly on the digestive tract content and fat deposition degree.

Carcass Dressing (CD) is important information as it represents the profitability of the edible portion and is the main parameter for producer compensation. The mean value for $\mathrm{CD}$ in this study was within the standard expected for lambs, ranging from 40 to $50 \%$. This variable is influenced by intrinsic (breed, sex, body condition and weight at slaughter), extrinsic factors (feed management and finishing system) and how it is calculated (Silva Sobrinho, 2001). True carcass dressing considers the weight of the empty gastrointestinal tract, so ranges from 53-56\% (Siqueira et al., 2000; Yamamoto et al., 2005; Zundt et al., 2006). The results obtained in this study for hot carcass corroborate with the cited authors (between 40 and 50\%) and are also close to true values $(53 \%)$.

In Table 6, the residual leaf area index had no effect on the parameters evaluated, but the supplementation 
increased depth of the chest and the external and internal carcass lengths. The variable length of the leg was not influenced by LAI or supplementation. This can be explained by the greater slaughter weight of animals receiving supplementation, which is consistent with the study by (Carvalho et al., 2007) that found greater internal carcass lengths in Ile de France $\times$ Corriedale animals slaughtered at $32 \mathrm{~kg}$ compared to $28 \mathrm{~kg}$.

Forage intake was negatively affected by increases in canopy structure residual Leaf Area Index (rLAI) -0.8 to 2.6). The animals in pastures with greater rLAI (2.6), had greater difficulty in harvesting the leaf forage due to lower availability of leaves in the upper layers, which decreases the size of the bite. With high rLAI the canopy density decreases which decrease the density of tillers and leaves which lead to reduced intake and is not compensated by bite size or bite rate (Ungar and NoyMeir, 1988). On the other hand, animals in pastures with lower rLAI (0.8), had no difficulty in harvesting the forage. Pastures with rLAI (0.8) have high availability of leaves in the upper layers, high canopy density and population of tillers and leaves. These animals can compensate lower rLAI with large bite size and higher bite rate.

These results are consistent with those found by (Dantas et al., 2008), that studied the carcass characteristics of lambs finished on pasture receiving three supplementation levels in the diet $(0.0,1.0$ and $1.5 \% \mathrm{BW})$. In their trial, they found longer carcasses for animals supplemented with $1.5 \%$ of BW compared to the control group. According to the author, it can be explained by the levels of protein and energy in the diet, resulting in higher deposition of muscle and adipose tissue.

Tables 7 shows the data for the weight $(\mathrm{kg})$ of regional carcass cuts of lambs finished on pasture with different LAI with supplementation or not. Supplementation increased the weight of cuts. This result can be explained by the fact that supplementation provided higher carcass weight, which may be related to the greater amount of muscle tissue in the supplemented treatment, confirming order of priority for tissue deposition; initially depositing bone followed by muscle and lastly, fat (Boggs et al., 1998). Similar results were reported by (Gonzaga Neto et al., 2006), when evaluating different concentrate levels (Silva Sobrinho, 2001; Ulbricht and Southgate, 1991 and 60\%) in the diets of lambs, where the authors observed a linear effect for weight of cuts as the concentrate inclusion increased in the diet. The differences obtained for cuts between treatments reflect, mainly, the increased growth of muscles for the supplemented animals.

Pointed out that animals slaughtered at heavier weights have heavier cuts than lighter animals, indicating increased deposition of muscle and adipose tissue, probably as a result of increased supply of nutrients. However, there were no effects of LAI on the weight of cuts (Silva Sobrinho, 2001).

The parameters of chemical composition were conducted on the Longissimus lumborum muscle of supplemented lambs finished in different LAI (Table 8) as well as total cholesterol levels, Saturated Fatty Acid (SFA), Monounsaturated Fatty Acid (MUFA), Polyunsaturated Fatty Acid (PUFA) and total collagen. Dry Matter (DM), Protein (PROT), Fat (FAT), Ash (ASH), saturated fatty acid, monounsaturated fatty acid, polyunsaturated fatty acid and total collagen were not influenced by the residual leaf area index, or supplementation. However, total cholesterol and elongase enzyme activity were influenced by supplementation only. Supplementation decreased the total cholesterol $(40.52,43.69)(p=0.0257)$, elongase enzyme activity $(69.69,71.17)(p=0.0067)$ and Atherogenicity index (ATHERO) and increased the polyunsaturated fatty acid $(9.28,8.99)(p=<0.0001)$, in comparison to the control group animals, respectively.

Table 5: Estimated means ( \pm standard error) for Body Length (BL), Anterior Height (AH), Posterior Height (PH), Thoracic Perimeter (THP), rump width (RW) e Thoracic Width (TW), according to the different Leaf Area Index (LAI), Supplemented or not (S)

\begin{tabular}{lllllll}
\hline Leaf Area Index $(\mathrm{LAI})$ & $\mathrm{BL}(\mathrm{cm})$ & $\mathrm{AH}(\mathrm{cm})$ & $\mathrm{PH}(\mathrm{cm})$ & $\mathrm{THP}(\mathrm{cm})$ & $\mathrm{RW}(\mathrm{cm})$ & $\mathrm{TW}(\mathrm{cm})$ \\
\hline 0.80 & $55.02 \pm 1.17$ & $63.32 \pm 1.22$ & $63.25 \pm 1.13$ & $71.83 \pm 1.56$ & $14.41 \pm 0.46$ & $20.46 \pm 0.70$ \\
1.40 & $53.12 \pm 1.17$ & $63.62 \pm 1.22$ & $64.25 \pm 1.13$ & $71.12 \pm 1.56$ & $14.43 \pm 0.46$ & $19.37 \pm 0.70$ \\
2.00 & $54.17 \pm 1.17$ & $64.30 \pm 1.22$ & $65.30 \pm 1.13$ & $69.60 \pm 1.56$ & $14.96 \pm 0.46$ & $20.45 \pm 0.70$ \\
2.60 & $52.93 \pm 1.17$ & $63.00 \pm 1.22$ & $62.87 \pm 1.13$ & $68.50 \pm 1.56$ & $15.06 \pm 0.46$ & $19.81 \pm 0.70$ \\
Supplementation (S) & & & & & \\
0.0 & $52.40 \pm 0.82^{\mathrm{B}}$ & $62.37 \pm 0.86$ & $62.77 \pm 0.79$ & $66.89 \pm 1.10^{\mathrm{B}}$ & $14.31 \pm 0.32$ & $18.95 \pm 0.49^{\mathrm{B}}$ \\
0.7 & $55.50 \pm 0.82^{\mathrm{A}}$ & $64.75 \pm 0.86$ & $65.06 \pm 0.79$ & $73.64 \pm 1.10^{\mathrm{A}}$ & $15.12 \pm 0.32$ & $20.59 \pm 0.49^{\mathrm{A}}$ \\
Variation sources & & & & & & \\
$P$-value LAI & 0.4858 & 0.8929 & 0.4434 & 0.4475 & 0.6549 & 0.2793 \\
$P$-value S & 0.0141 & 0.0652 & 0.0546 & 0.0002 & 0.0918 & 0.0290 \\
$P$-value LAI x S & 0.4963 & 0.5817 & 0.5700 & 0.0984 & 0.1134 & 0.7050 \\
\hline
\end{tabular}

Means with equal capital letters within row do not differ by Tukey test $(p>0.05)$ 
Table 6: Estimated means ( \pm standard error) for Total Intake of Dry Matter (TIDM, kg animal ${ }^{-1}$ day $\left.^{-1}\right)$, Average DAILY gain (ADG, kg), Slaughter Weight (SW, kg), Hot Carcass Weight (HCW, kg), Cold Carcass Weight (CCW, kg), Empty Body Weight (EBW, kg), carcass yield (CY,\%), External Carcass Length (ECL, cm), internal Carcass Length (ICL, cm) and Thoracic Depth (THD, cm), according to the different Leaf Area Index (LAI), Supplemented or not (S)

\begin{tabular}{|c|c|c|c|c|c|c|c|c|c|c|}
\hline Leaf Area Index (LAI) & TCDM & $\mathrm{ADG}$ & SW & HCW & $\mathrm{CCW}$ & EBW & $\mathrm{CY}$ & ECL & ICL & THD \\
\hline$\overline{0.80}$ & $0.771 \pm 0.91$ & $0.127 \pm 1.09$ & $26.22 \pm 1.28$ & $10.05 \pm 0.61$ & $9.68 \pm 0.60$ & $21.09 \pm 1.15$ & $47.68 \pm 1.02$ & $49.76 \pm 0.92$ & $55.00 \pm 0.78$ & $25.60 \pm 0.44$ \\
\hline 1.40 & $0.803 \pm 0.91$ & $0.122 \pm 1.09$ & $25.71 \pm 1.28$ & $9.45 \pm 0.61$ & $9.12 \pm 0.60$ & $20.40 \pm 1.15$ & $46.05 \pm 1.02$ & $49.56 \pm 0.92$ & $55.87 \pm 0.78$ & $24.85 \pm 0.44$ \\
\hline 2.00 & $0.733 \pm 0.91$ & $0.131 \pm 1.09$ & $26.60 \pm 1.28$ & $10.47 \pm 0.61$ & $10.12 \pm 0.60$ & $21.69 \pm 1.15$ & $47.99 \pm 1.02$ & $48.93 \pm 0.92$ & $55.83 \pm 0.78$ & $25.26 \pm 0.44$ \\
\hline 2.60 & $0.746 \pm 0.91$ & $0.118 \pm 1.09$ & $25.36 \pm 1.28$ & $9.54 \pm 0.61$ & $9.23 \pm 0.60$ & $19.17 \pm 1.15$ & $47.34 \pm 1.02$ & $48.56 \pm 0.92$ & $55.37 \pm 0.78$ & $24.47 \pm 0.44$ \\
\hline \multicolumn{11}{|l|}{ Supplementation (S) } \\
\hline 0.0 & $0.782 \pm 0.74$ & $0.093 \pm 0.66^{\mathrm{B}}$ & $22.73 \pm 0.90^{\mathrm{B}}$ & $8.59 \pm 0.43^{\mathrm{B}}$ & $8.28 \pm 0.42^{\mathrm{B}}$ & $18.53 \pm 0.81^{\mathrm{B}}$ & $46.08 \pm 0.72^{\mathrm{B}}$ & $47.09 \pm 0.65^{\mathrm{B}}$ & $55.10 \pm 0.55^{\mathrm{B}}$ & $24.33 \pm 0.31^{\mathrm{B}}$ \\
\hline 0.7 & $0.769 \pm 0.74$ & $0.147 \pm 0.66^{\mathrm{A}}$ & $28.21 \pm 0.90^{\mathrm{A}}$ & $11.17 \pm 0.43^{\mathrm{A}}$ & $10.79 \pm 0.42^{\mathrm{A}}$ & $22.65 \pm 0.81^{\mathrm{A}}$ & $48.45 \pm 0.72^{\mathrm{A}}$ & $51.31 \pm 0.65^{\mathrm{A}}$ & $56.43 \pm 0.55^{\mathrm{A}}$ & $25.76 \pm 0.31^{\mathrm{A}}$ \\
\hline Variation sources & \multicolumn{10}{|c|}{ Significance level } \\
\hline$P$-value LAI & 0.0971 & 0.0691 & 0.5380 & 0.6214 & 0.6352 & 0.4669 & 0.5630 & 0.7837 & 0.0552 & 0.3218 \\
\hline P-value $\mathrm{S}$ & 0.1093 & 0.0472 & 0.0003 & 0.0003 & 0.0003 & 0.0016 & 0.0295 & 0.0001 & 0.0003 & 0.0036 \\
\hline$P$-value LAI x S & 0.1305 & 0.0902 & 0.1260 & 0.1022 & 0.0985 & 0.2820 & 0.3654 & 0.0921 & 0.1550 & 0.4290 \\
\hline
\end{tabular}

Means with equal capital letters within row do not differ by Tukey test $(p>0.05)$

Table 7: Estimated means ( \pm standard error) for half carcass $(1 \backslash 2 \mathrm{CW})$, Gammon $(\mathrm{GW})$, Shoulder (SW), Loin (LW), Rib Weights (RW), Subcutaneous Fat Thickness (SFT) and Ribeye Area (REA), according to the different Leaf Area Index (LAI), Supplemented or not (S)

\begin{tabular}{|c|c|c|c|c|c|c|c|}
\hline Leaf Area Index (LAI) & $1 \backslash 2 \mathrm{CW}(\mathrm{kg})$ & GW (kg) & PW (kg) & $\mathrm{LW}(\mathrm{kg})$ & RW (kg) & SFT (mm) & $\operatorname{REA}\left(\mathrm{cm}^{2}\right)$ \\
\hline 0.80 & $4.41 \pm 0.35$ & $1.66 \pm 0.11$ & $1.01 \pm 0.07$ & $0.28 \pm 0.02$ & $1.49 \pm 0.11$ & $0.036 \pm 0.006$ & $9.32 \pm 0.54$ \\
\hline 1.40 & $4.12 \pm 0.35$ & $1.53 \pm 0.11$ & $0.95 \pm 0.07$ & $0.29 \pm 0.02$ & $1.49 \pm 0.11$ & $0.040 \pm 0.006$ & $10.24 \pm 0.54$ \\
\hline 2.00 & $4.58 \pm 0.35$ & $1.62 \pm 0.11$ & $1.09 \pm 0.07$ & $0.31 \pm 0.02$ & $1.48 \pm 0.11$ & $0.043 \pm 0.006$ & $10.86 \pm 0.54$ \\
\hline 2.60 & $4.68 \pm 0.35$ & $1.60 \pm 0.11$ & $0.93 \pm 0.07$ & $0.28 \pm 0.02$ & $1.47 \pm 0.11$ & $0.041 \pm 0.006$ & $10.68 \pm 0.54$ \\
\hline \multicolumn{8}{|l|}{ Supplementation (S) } \\
\hline 0.0 & $3.95 \pm 0.24^{\mathrm{B}}$ & $1.56 \pm 0.08^{\mathrm{B}}$ & $0.90 \pm 0.05^{\mathrm{B}}$ & $0.25 \pm 0.01^{\mathrm{B}}$ & $1.29 \pm 0.08^{\mathrm{B}}$ & $0.043 \pm 0.004$ & $10.51 \pm 0.38$ \\
\hline 0.7 & $4.95 \pm 0.24^{\mathrm{A}}$ & $1.79 \pm 0.08^{\mathrm{A}}$ & $1.09 \pm 0.05^{\mathrm{A}}$ & $0.33 \pm 0.01^{\mathrm{A}}$ & $1.67 \pm 0.08^{\mathrm{A}}$ & $0.036 \pm 0.004$ & $9.99 \pm 0.38$ \\
\hline Variation Sources & \multicolumn{7}{|c|}{ Significance level } \\
\hline$P$-value LAI & 0.6931 & 0.2230 & 0.4879 & 0.9071 & 0.9988 & 0.8525 & 0.1715 \\
\hline P-value $\mathrm{S}$ & 0.0087 & 0.0096 & 0.0227 & 0.0053 & 0.0038 & 0.2719 & 0.3443 \\
\hline$P$-value LAI x S & 0.3345 & 0.5448 & 0.2606 & 0.2208 & 0.1321 & 0.7931 & 0.8815 \\
\hline
\end{tabular}

Means with equal capital letters within row do not differ by Tukey test $(p>0.05)$

Table 8: Estimated means ( \pm standard error) for Dry Matter (DM,\%), Protein (PROT,\%), Fat (FAT,\%), Ash (ASH, \%), total Cholesterol (CLT, mg/100g), Saturated Fatty Acid (SFA \%), Monounsaturated Fatty Acid (MUFA \%), Polyunsaturated Fatty Acid (PUFA,\%), Elongase Enzyme Activity (ELONG), Atherogenicity Index (ATHERO) and total Collagen (COL, mg/g) of longissimus lumborum muscle, according to the different Leaf Area Index (LAI), Supplemented or not (S)

\begin{tabular}{|c|c|c|c|c|c|c|c|c|c|c|c|}
\hline Leaf Area Index (LAI) & DM & PROT & FAT & ASH & CLT & SFA & MUFA & PUFA & ELONG & ATERO & $\mathrm{COL}$ \\
\hline 0.80 & $23.68 \pm 3.52$ & $20.72 \pm 1.48$ & $1.27 \pm 2.59$ & $1.22 \pm 1.93$ & $44.21 \pm 2.57$ & $50.96 \pm 0.05$ & $32.14 \pm 0.08$ & $9.90 \pm 0.03$ & $71.09 \pm 0.02$ & $0.4987 \pm 0.006$ & $2.23 \pm 1.32$ \\
\hline 1.40 & $21.80 \pm 3.52$ & $19.26 \pm 1.48$ & $1.37 \pm 2.59$ & $1.31 \pm 1.93$ & $45.95 \pm 2.57$ & $52.79 \pm 0.05$ & $33.23 \pm 0.08$ & $9.61 \pm 0.03$ & $70.81 \pm 0.02$ & $0.5057 \pm 0.006$ & $2.41 \pm 1.32$ \\
\hline 2.00 & $21.43 \pm 4.21$ & $20.39 \pm 1.77$ & $1.34 \pm 3.10$ & $1.41 \pm 2.30$ & $43.35 \pm 3.07$ & $52.42 \pm 0.05$ & $32.21 \pm 0.08$ & $9.66 \pm 0.03$ & $70.79 \pm 0.02$ & $0.5063 \pm 0.006$ & $2.31 \pm 1.58$ \\
\hline 2.60 & $22.71 \pm 3.52$ & $18.78 \pm 1.48$ & $1.21 \pm 2.59$ & $1.45 \pm 1.93$ & $43.92 \pm 2.57$ & $51.84 \pm 0.05$ & $32.32 \pm 0.08$ & $9.26 \pm 0.03$ & $71.04 \pm 0.02$ & $0.4966 \pm 0.006$ & $2.20 \pm 1.32$ \\
\hline \multicolumn{12}{|l|}{ Supplementation (S) } \\
\hline 0.0 & $23.75 \pm 2.58$ & $21.09 \pm 1.08$ & $1.17 \pm 1.90$ & $1.17 \pm 1.41$ & $43.69 \pm 1.88^{\mathrm{A}}$ & $52.36 \pm 0.03$ & $33.05 \pm 0.06$ & $9.28 \pm 0.02$ & $71.17 \pm 0.02^{\mathrm{A}}$ & $0.4993 \pm 0.004^{\mathrm{A}}$ & $2.52 \pm 0.97$ \\
\hline 0.7 & $22.07 \pm 2.66$ & $20.44 \pm 1.11$ & $1.42 \pm 1.96$ & $1.69 \pm 1.46$ & $40.52 \pm 1.94^{\mathrm{B}}$ & $51.15 \pm 0.03$ & $32.87 \pm 0.06$ & $8.99 \pm 0.02$ & $69.69 \pm 0.02^{\mathrm{B}}$ & $0.4804 \pm 0.004^{\mathrm{B}}$ & $2.56 \pm 1.00$ \\
\hline Varia & \multicolumn{11}{|c|}{ Significance level } \\
\hline$P$-value LAI & 0.1517 & 0.7862 & 0.9740 & 0.4581 & 0.3435 & 0.3309 & 0.4401 & 0.4 & 0.2 & 0.2 & 0.2320 \\
\hline P-value $\mathrm{S}$ & 0.0533 & 0.1056 & 0.3620 & 0.1084 & 0.0257 & 0.1146 & 0.6566 & 0.2 & 0.0067 & 0.0216 & 0.1621 \\
\hline P-value LAI x S & 0.0994 & 0.5899 & 0.5500 & 0.1026 & 0.8051 & 0.2165 & 0.3368 & 0.0978 & 0.0905 & 0.1097 & 0.1013 \\
\hline
\end{tabular}

Means with equal capital letters within row do not differ by Tukey test $(p>0.05)$

The chemical composition of lamb meat presents average values of $75 \%$ moisture, $19 \%$ protein, $4 \%$ fat, $1.1 \%$ mineral matter and less than $1 \%$ of carbohydrates. Except for the ether extract values, other values obtained in this study were similar to those cited by the author (Prata, 1999). The ether extract content of lamb meat has large variation, mainly due to the diet, weight and age at slaughter, breed, sex and muscle deposition (Madruga et al., 2005).

The chemical composition of meat can be influenced by different factors such as breed, sex, nutrition and slaughter weight. Gaili et al. (1972) studied the Longissimus lumborum muscle of goats and lambs, slaughtered at different ages and observed that younger animals had higher protein, ash and fat content than older animals. Thus, the data obtained in this study can be explained by the young age of slaughter (7-8 months), because the accumulation of subcutaneous and intramuscular fat is lower in young animals (Lawrie, 2005; Zapata et al., 2003). For (Berg and Butterfield, 1976), maturity is reflected by an increase in the proportion of fat, accompanied by a decrease in the proportion of water and protein in the body.

The difference of total cholesterol between the nonsupplemented or supplemented animals, can be explained by the difference in the elongase enzyme activity. The supplemented animals showed lower average activity of the enzyme elongase compared 
control group animals, 69.69 and 71.17, respectively. This enzyme increases the number of carbons in the carbon chain, participating in the formation of polyunsaturated fatty acids and total cholesterol (Sargent, 1997). Spritz and Misual (1969) reported that diet has more influence on the amount of cholesterol of the meat than breed or genetic group. The amount of cholesterol increases as unsaturated fatty acids decrease.

Atherogenicity index were greater for the control group in comparison to the supplemented animals. This fact makes the meat of these animals more likely to cause problems for human health, increasing the incidence of atheromas or even death. Some trials showed that in meat and dairy products the predominance of saturated fat is associated with increased blood cholesterol, which increases the risk of clogged arteries and may lead to coronary heart disease and even death (Taubes, 2001). Ulbricht and Southgate (1991) proposed that an ideal atherogenicity index would be lower than 1.27. Using this information, the consumption of meat from either supplemented or control group animals would not cause any health problems to the consumer. However, consuming meat from supplemented animals may be healthier considering the lower atherogenicity index.

The average cholesterol levels obtained in this study were lower compared to those obtained by (Rowe et al., 1999), who found values of 62.03 and $57.76 \mathrm{mg} / 100 \mathrm{~g}$ in samples of lamb finished on pasture or confined, respectively. In contrast, Madruga et al. (2005) found cholesterol values closer to those obtained in this study, with $44.10 \mathrm{mg} / 100 \mathrm{~g}$ in meat of Santa Inês lamb finished with $60 \%$ roughage diets.

The participation of collagen in meat tenderness is related to the total collagen content and its solubility (Young and Braggins, 1993; Ramos and Gomide, 2005). It can be quantified by hydroxyproline content, which is an amino acid present almost exclusively in collagen and is directly related to the thermal stability (Gaili et al., 1972). Soluble collagen content influences the tenderness of the meat in animals of different ages, while the total content predicts differences in tenderness between muscles (Ramos and Gomide, 2005). With increasing age of the animals, the collagen is modified by number of cross-linkages, making it more resistant to cutting. Animals in this study were a similar age, therefore significant differences in shear force and total collagen content could not be detected. Díaz et al. (2002) evaluated the meat quality of lambs in different production systems and obtained collagen levels higher than those found in this study for animals finished on pasture, $2.47 \mathrm{mg}$ per gram of muscle.

Table 9 shows the averages for $\mathrm{L}^{*}, \mathrm{a}^{*}, \mathrm{~b}^{*}, \mathrm{pH} 45$ min after slaughter and $\mathrm{pH} 24 \mathrm{~h}$ after slaughter, along with CL, WHC and shear force in the Longissimus lumborum muscle, according to the LAI being supplemented or not. The parameters were not influenced the different treatments.

Faria et al. (2001) described meat trait values from 31.36 to 38.0 for $\mathrm{L}^{*}, 12.27$ to 18.01 for $\mathrm{a}^{*}$ and 3.34 to 5.65 for $b^{*}$. In the present experiment, the values of $a^{*}$ and $b^{*}$ are within these ranges, but the $L^{*}$ values were greater. The results of this study are similar to those found by (Sañudo et al., 1992), who studied the quality of lamb meat with different carcass weights and found means for $\mathrm{L}^{*}$ between 45.61 and 48.15 , a* between 13.94 and 16.95 and $b^{*}$ between 5.90 and 6.02 . According to (Boggs et al., 1998), observing a drop in meat $\mathrm{pH}$ suggests that other quality parameters such as WHC, tenderness and color, will present good results, because they are influenced by $\mathrm{pH}$.

The average values of CL were close to those found by (Lloyd et al., 1981) and (Kadim et al., 1993), being 25.95 and $16.12 \%$, respectively. However, these values were lower than $36.48 \%$ obtained by (Bonagurio, 2001) in Santa Inês lambs. Rota et al. (2004) reported values above $73 \%$. However, values observed in this study indicate that the meat presented no exudative problems and was within the range considered normal for lambs (Rota et al., 2004).

The values obtained for shear force characterize the meat of the present study as medium softness because according to (Cezar and Sousa, 2004), ovine meat that exhibit SF values lower than $22.26 \mathrm{~N}$; from 22.36 to $35.60 \mathrm{~N}$; from $35.69 \mathrm{~N}$ to $53.34 \mathrm{~N}$ and above $53.34 \mathrm{~N}$, can be classified as soft, medium soft, hard and extremely hard, respectively. Grazziotin et al. (2002), studied the effect of the pasture availability and breed on carcass and meat characteristics of lambs and found values for shear force between 31.18 and $32.36 \mathrm{~N}$, similar to those obtained in the present experiment.

There was no difference on the frequency in the area $\left(\mu \mathrm{m}^{2}\right)$ and total relative area $\left(\mu \mathrm{m}^{2}\right)$ for SO, FOG and FG of muscular fibers from lambs submitted to different LAI being supplemented or not. This result shows that diet had no influence on these parameters. The proportion of the types of muscle fibers can be related to meat tenderness. Calkins et al. (1981) found a significant correlation between the oxidative muscle fibers ( $\mathrm{SO}$ and FOG) and marbling rate, consequently, affecting the tenderness of the meat. Moody et al. (1980) and (Ockerman et al., 1984) found a significant positive correlation between the red fibers (SO and FOG) and the tenderness of the meat. In this study, the tenderness showed a positive and significant correlation $(p<0.05)$ with $\mathrm{CL}$, reflecting the importance of evaluating the qualitative parameters that influence the quality of the meat product. 
Table 9: Estimated means ( \pm standard error) for Lightness $\left(\mathrm{L}^{*}\right)$, red intensity $\left(\mathrm{a}^{*}\right)$, yellow intensity $\left(\mathrm{b}^{*}\right)$, $\mathrm{pH} 45$ min after slaughter (pH45), pH $24 \mathrm{~h}$ after slaughter (pH24), Cooking Loss (CL), Water Holding Capacity (WHC) and Shear Force (SF) in the longissimus lumborum muscle, according to the different Leaf Area Index (LAI), Supplemented or not (S)

\begin{tabular}{lllllllll}
\hline Leaf Area Index (LAI) & $\mathrm{L}^{*}$ & $\mathrm{a}^{*}$ & $\mathrm{~b}^{*}$ & $\mathrm{pH} 45$ & $\mathrm{pH} 24$ & $\mathrm{PPC}(\%)$ & $\mathrm{CRA}(\%)$ & $\mathrm{SF}(\mathrm{N})$ \\
\hline 0.80 & $40.42 \pm 2.80$ & $14.88 \pm 1.85$ & $3.90 \pm 0.70$ & $6.69 \pm 2.72$ & $5.93 \pm 0.07$ & $27.27 \pm 2.23$ & $64.80 \pm 1.04$ & $31.60 \pm 2.41$ \\
1.40 & $39.57 \pm 2.80$ & $15.22 \pm 1.85$ & $4.47 \pm 0.70$ & $6.66 \pm 2.72$ & $5.77 \pm 0.07$ & $24.50 \pm 2.23$ & $63.77 \pm 1.04$ & $31.00 \pm 2.41$ \\
2.00 & $40.54 \pm 2.73$ & $14.23 \pm 2.21$ & $3.83 \pm 0.84$ & $6.31 \pm 2.72$ & $5.76 \pm 0.07$ & $27.29 \pm 2.67$ & $63.88 \pm 1.24$ & $29.68 \pm 2.88$ \\
2.60 & $40.34 \pm 2.80$ & $15.32 \pm 1.85$ & $4.16 \pm 0.70$ & $6.49 \pm 2.72$ & $5.79 \pm 0.07$ & $22.15 \pm 2.23$ & $64.85 \pm 1.04$ & $29.68 \pm 2.41$ \\
Supplementation (S) & & & & & & & & \\
0.0 & $39.91 \pm 2.51$ & $14.87 \pm 1.35$ & $4.65 \pm 0.51$ & $6.65 \pm 1.99$ & $5.85 \pm 0.10$ & $25.27 \pm 1.63$ & $63.59 \pm 0.76$ & $30.58 \pm 1.76$ \\
0.7 & $39.52 \pm 2.63$ & $14.45 \pm 1.40$ & $4.44 \pm 0.53$ & $6.38 \pm 2.06$ & $5.78 \pm 0.10$ & $25.33 \pm 1.69$ & $65.06 \pm 0.78$ & $30.40 \pm 1.82$ \\
Variation sources & & & & Significance level & & & \\
$P$-value LAI & 0.1210 & 0.1592 & 0.2939 & 0.5008 & 0.3217 & 0.3608 & 0.8336 & 0.9288 \\
$P$-value S & 0.2225 & 0.2317 & 0.1210 & 0.2561 & 0.3586 & 0.9822 & 0.1939 & 0.9439 \\
$P$-value LAI x S & 0.6416 & 0.2004 & 0.8098 & 0.3787 & 0.8884 & 0.8263 & 0.4478 & 0.6529 \\
\hline
\end{tabular}

Means with equal capital letters within row do not differ by Tukey test $(p>0.05)$.

In this study, a low and negative correlation $(-0.21)$ between SF and frequency of FG fiber in longissimus Lumborum muscle of Santa Inês lambs was also observed. It is evident that there are numerous effects that can interfere with tenderness of the longissimus muscle. Among these important effects are antemortem factors (diet and pre-slaughter management) and post-mortem factors (cooling, handling and packaging). Given the above, researchers not only have to take into account breeding systems, but also feed management and all the points that can compromise the quality of the meat. Koohmaraie et al. (2003) reported that if considering the same breed regardless of the species, $30 \%$ of the tenderness and or meat quality can be attributed to the genotype of the animal. The other $70 \%$ can be attributed to environmental factors that can directly influence the meat quality ultimately consumed by the consumer.

\section{Conclusion}

Providing supplements for sheep improves the carcass composition such as hot carcass weight, cold carcass weight, empty body weight, carcass dressing, external and internal carcass lengths and thoracic depth. Additionally, supplementation improves the slaughter weight, which is the most important parameter for the producer's profitability. Although the use of supplements involves the increase of production costs, it provides quantitative and qualitative characteristics favorable to the product, aiming to satisfy the consumer market. The meat from supplemented animals is healthier to be consumed compared to control group animals, due to the low atherogenicity index.

\section{Acknowledgement}

This work was supported by the São Paulo Research Foundation (Fundação de Amparo à Pesquisa do Estado de São Paulo) - FAPESP \{2010/1896-9].

\section{Author's Contributions}

All the authors contributed with trial conducting, physical and chemical analysis, statistical analysis and writing.

\section{Ethics}

The authors confirm that the present article is original and no ethical issues are concerned with it.

\section{References}

AOAC, 1990. Official Methods of Analysis of the Association of Official Analytical Chemists. 15th Edn., Association of official analytical chemists, ISBN-10: 0935584420.

AOAC, 1995. Official Methods of Analysis Association of Official Analytical Chemists. 16th Edn., Washington.

Barros, N.N., 2013. Acabamento de cordeiros em confinamento. Disponível em:

Berg, R.T. and R.M. Butterfield, 1976. New concepts of cattle growth. Sidney University. Press, Sidney,

Boggs, D.L., R.A. Merkel and M.E. Doumit, 1998. Livestock and carcasses: An integrated approach to evaluation, grading and selection. Hunt, Kenda,

Bonagurio, S., 2001. Qualidade da carne de cordeiros Santa Inês puros e mestiços com Texel abatidos com diferentes pesos (Meat quality of pure and crossbread Santa Inês lambs with Texel slaughtered with diferente weights). Lavras: Federal University of Lavras, 2001. 150p. Dissertação (Master's degree in Animal Science) - Federal University of Lavras.

Calkins, C.R., T.R. Dutson, G.C. Smith and Z.L. Carpenter, 1981. Davis GW: Relationship of fiber type composition to marbling and tenderness of bovine muscle. J. Food Sci., 46: 708-710. DOI: 10.1111/j.1365-2621.1981.tb15331.x 
Carvalho, S., M.A. Brochier, J. Pivato, R.C. Teixeira and R. Kieling, 2007. Ganho de peso, características da carcaça e componentes não-carcaça de cordeiros da raça Texel terminados em diferentes sistemas alimentares (Weight gain,carcass characteristics and non-carcass componentes of Texel lambs fe don different Food systems) (In English). Cienc Rural, 37: 821-827. DOI: 10.1590/S0103-84782007000300034

Cezar, M.F. and W.H. Sousa, 2007. Sheep and goat carcasses: obtaining, evaluation and classification (Carcaças ovinas e caprinas: obtenção, avaliação e classificação) (in Portuguese). Agropecuária Tropical.

Colomer-Rocher, F., R. Delfa and I. Sierra, 1998. Método normalizado para el estúdio de los caracteres cuantitativos y cualitativos de las canales, según los sistemas de produccíon. In: Método normalizado para el estudio de los caracteres cuantitativos y cualitativos de las canales caprinas y ovinas. Madrid: INIA 1998: 19-41.

Dantas, A.F., J.M. Pereira Filho, A.M.A. Silva, E.M. Santos and B.B. Sousa et al., 2008. Características da carcaça de ovinos Santa Inês terminadas em pastejo e submetidas a diferentes níveis de suplementação (Carcass characteristics of Santa Inês lamb grazed and submitted to different levels of supplementation) (In English). Cienc Agrotec.

Díaz, M.T., S. Velasco, V. Cañeque, S. Lauzurica and F.R. Huidobro et al., 2002. Use of concentrate or pasture for fattening lambs and its effect on carcass and meat quality. Small Ruminant Res., 43: 257- 268. DOI: 10.1016/S0921-4488(02)00016-0

Dubowitz, V. and M.H. Brooke, 1973. Muscle biopsy: A modern approach. Saunders, London,

Faria, P.B., M.C. Bressan and S.H.I. Oda, 2001. Características De pH e Cor (CIELAB) De Carne De Capivaras (Hydrochaeris hydrochaeris L. 1766) Nas Primeiras 24h Post Mortem. In: Simpósio Latino Americano de Ciência de Alimentos, 4., 2001, Campinas. Anais... Campinas, p: 157.

Flores, E.R., E.A. Laca, T.C. Griggs and M.W. Demment, 1993. Sward height and vertical morphological differentiation determine cattle bite dimensions. Agron. J., 85: 527-532. DOI: 10.2134 /agronj 1993.00021962008500030001x

Gaili, E.S.E., Y.S. Ghanem and A.M.S. Mukhtar, 1972. A comparative study of some carcass characteristics of Sudan desert sheep and goats. Anim. Prod., 14: 351-357. DOI: $10.1017 / \mathrm{S} 0003356100011089$

Gonzaga Neto, S., A.G. Silva Sobrinho, N.M.L. Zeola, C.A.T. Marques and A.M.A. Silva et al., 2006. Características quantitativas da carcaça de cordeiros deslanados Morada Nova em função da relação volumoso: concentrado na dieta (Quantitative carcass characteristics of Morada Nova lambs as a função of the voluminous: Concentrate ratio in the diet). Rev. Bras. Zootecn.
Grazziotin, M.S., H.O. Patiño, J.M. Rubensam, P.F. Carvalho and E. Schreiner, 2002. Efeito da disponibilidade do pasto e da raça sobre características de carcaça e da carne de cordeiros. In: Reunião Anual da Sociedade Brasileira de Zootecnia, Recife. Anais. Sociedade Brasileira de Zootecnia, Recife.

Hamm, R., 1977. Physical, Chemical and Biological Changes in Food Caused by Thermal Processing. 23th Edn., Applied Science, ISBN-10: 0853347298, pp: 398.

Holden, L.A., 1999. Comparison of methods of in vitro dry matter digestibility for ten feeds. J. Dairy Sci., 82: 1791-1794. DOI: 10.3168/jds.S0022-0302(99)75409-3

Kadim, I.T., R.W. Purchas, A.S. Davies, A.L. Rae and R.A. Barton, 1993. Meat quality and muscle fiber type characteristics of southdown rams from high and low back fat selection lines. Meat Sci., 33: 97-109. DOI: 10.1016/0309-1740(93)90097-2

Klont, R.E., L. Brocks and G. Eikelenboom, 1998. Muscle fibre type and meat quality. Meat Sci., 49: 219-229. DOI: 10.1016/S0309-1740(98)90050-X

Koohmaraie, M., D.A. King and S.D. Shackelford, 2003. Understanding and Managing Variation in Meat Tenderness. In: Reunião Anual Da Sociedade Brasileira De Zootecnia, Santa Maria. Anais. UFSM, Santa Maria.

Laca, E.A., E.D. Ungar, N. Seligman and M.W. Demment, 1992. Effects of sward height and bulk density on bite dimensions of cattle grazing homogeneous swards. Grass Forage Sci., 47: 91-102.

DOI: $10.1111 / \mathrm{j} .1365-2494.1992 . t b 02251 . x$

Lage, J.F., 2009. Glicerina bruta oriunda da agroindústria do biodiesel na alimentação de cordeiros em terminação. 72 f. Dissertação (Mestrado em Zootecnia) -Universidade Federal de Viçosa - MG. Viçosa.

Lawrie, R.A., 2005. Ciência da Carne. 6th Edn., São Paulo: Artmed, ISBN-10: 8536304596, pp: 384.

Lloyd, W.R., A.L. Slyter and W.J. Costello, 1981. Effect of breed, sex and final weight on feedlot performance, carcass characteristics and meat palatability of lambs. J. Anim. Sci., 51: 316-320. DOI: $10.2527 /$ jas $1980.512316 x$

Macedo, F.A.F., E.R. Siqueira, E.M. Martins and R.M.G. Macedo, 2000. Qualidade de carcaças de cordeiros Corriedale, Bergamácia $\mathrm{x}$ Corriedale e Hampshire Down $\mathrm{x}$ Corriedale, terminados em pastagem e confinamento (Carcass quality from Corriedale, Bergamácia x Corriedale and Hampshire Down x Corriedale lamb finished in pasture and fedlot lamb (In English). Rev. Bras. Zootecn., 29: 1520-1527. DOI: 10.1590/S1516-35982000000500034

Madruga, M.S., W.H. Sousa, M. Rosales, M.G.G. Cunha and J.L.F. Ramos, 2005. Qualidade da carne de cordeiros Santa Inês terminados com diferentes dietas (Meat quality of Santa Inês lambs finished with different diets) (In English). Rev. Bras. Zootecn. 
Martinez, D.E., F.A.G. Nuñez, A.M. García, A.T. Blanca, 2001. Caracterización de canales de borregos alimentados con desechos de papel. Rev. Bras Agrocie.

Molento, M.B., C. Tasca, A. Gallo, M. Ferreira and R. Bononi et al., 2004. Famacha method as an individual clinical parameter of Haemonchus contortus infection in small ruminants (Método Famacha como parâmetro clínico individual de infecção por Haemonchus contortus em pequenos ruminantes) (in Portuguese). Cienc, Rural.

Monteiro, E.M., S. Massami, D.P.S. Maily and D.P. Vitalino, 2000. Efeitos do genótipo nas características morfológicas e histoquímicas do Longissimus dorsi e em alguns parâmetros quantitativos das carcaças de cordeiros (Effects of genotype on the morphological and histochemical characteristics of longissimus dorsi on some quantitative Parameters of lamb carcasses) (In English). Cienc Agrotec.

Moody, W.G., J.D. Kemp, M. Mahyuddin, D.M. Johnston and DG. Ely, 1980. Effect of feeding system, slaughter weight and Sex on histological properties of lambs carcasses. J. Anim. Sci., 50: 249-256. DOI: $10.2527 /$ jas 1980.502249x

Ockerman, H.W., D. Jaworek, B. Van Starvern, N. Parret and C.J. Pierson, 1984. Castration and sires effects on carcass traits, meat palatability and muscle fiber characteristics in Angus cattle. J. Anim. Sci., 59: 981-990. DOI: 10.2527/jas1984.594981x

Ono, S., H. Abe, R. Nagaoka and T. Obinata, 1993. Colocalization of ADF and cofilin in intranuclear actin rods of cultured muscle cells. J. Muscle Res. Cell M, 14: 195-204. DOI: 10.1007/BF00115454

Pires, C.C., L.F. Silva, E. Schlick, D.P. Guerra and G. Biscaino et al., 2000. Cria e terminação de cordeiros confinados (Create and finishing of lambs in feedlot) (In English). Cienc Rural,

Prata, L.F., 1999. Higiene e inspeção de carnes, pescado e derivados (Hygiene and inspection of meat, fish and fish prodcuts) (In English). FUNEP, Jaboticabal.

Ramos, E.M. and L.A.M. Gomide, 2007. Evaluation of abnormal meat: PSE and DFD conditions. In "Evaluation of Meat Quality: Fundamentals and Methodologies" (Avaliação de carnes anormais: condições PSE e DFD. In 'Avaliação da qualidade de carnes: Fundamentos e metodologias') (in Portuguese) Ramos, E.M. and L.A.M. Gomide (Eds.), Federal University of Viçosa: Viçosa, Minas Gerais, Brazil, pp: 531-575.

Rota, E.L., M.T.M. Osório, J.C.S. Osório, N.M. Oliveira and J. Barboza et al., 2004. Efeitos do cruzamento de carneiros da raça Texel com ovelhas Corriedale e Ideal sobre a qualidade da carne (Effect of crossbreeding of Texel sheep with Corriedale and ideal sheep on meat Quality) (In English). Rev. Bras. Agrocienc.
Rowe, A., F.A.F. Macedo, J.V. Vicentainer, N.E. Souza and M. Matsushita, 1999. Muscle composition and fatty acid profile in lambs fattened in drylot or pasture. Meat Sci., 51: 283-288. DOI: $10.1016 / \mathrm{S} 0309-1740(98) 00063-1$

Sañudo, C., I. Sierra and M.J. Alcalde, 1992. Calidad de la canal en corderos ligeros tipo ternasco, canales españolas y de importación (Carcass quality of light ternasco lambs, Spanish and import channels) (In English). Información Técnica Económica Agraria.

Sargent, J.R., 1997. Fish oils and human diet. Brit J. Nutr., 78: 55-513. DOI: 10.1079/BJN19970131

SAS, 2002. User's guide: Statistics. SAS Institute.

Sazili, A.Q., T. Parr, P.L. Sensky, S.W. Jones and R.G. Bardsley et al., 2005. The relationship between slow and fast myosin heavy chain content, calpastatin and meat tenderness in different ovine skeletal muscles. Meat Sci., 69: 17-25.

DOI: $10.1016 /$ j.meatsci.2004.06.021

Senger, C.C.D., G.V. Kozloski, L.M.B. Sanchez, F.R. Mesquita and T.P. Alves et al., 2008. Evaluation of autoclave procedures for fiber analysis in forage and concentrate feedstuffs. Anim. Feed Sci. Technol., 146: 169-174. DOI: 10.1016/j.anifeedsci.2007.12.008

Silva Sobrinho, A.G., 2001. Criação de ovinos. FUNEP, Jaboticabal.

Silva, D.J. and A.C. Queiroz, 2002. Análise de alimentos-métodos químicos e biológicos.

Silva, W.L., 2014. Características estruturais do dossel, produção de forragem e desempenho de cordeiros em pastos de tifton 85 sob lotação intermitente. Tese (Doutorado em Zootecnia)-universidade estadual paulista "júlio de mesquita filho"faculdade de ciências agrárias e veterinárias-campus de Jaboticabal-SP.

Siqueira, E.R., C.D. Simões and S. Fernandes, 2000. Efeito do genótipo e do peso sobre a produção de carne de cordeiros. Velocidade de crescimento, caracteres quantitativos da carcaça, $\mathrm{pH}$, da carne e resultado económico (Effect of genotype and weight on the Production of meat lamb. Growth rate, quantitative carcass traits, $\mathrm{pH}$, meat and economic results) (In English). Rev. Bra. Zootecn.

Spritz, N. and M.A. Misual, 1969. Effects of dietary fats on plasma lipids and lipoproteins: A hypothesis for the lipid-lowering effect of unsaturated fatty acids. J. Clin. Invest.

Stockdale, F.E., 1992. Myogenic cell lineages. Dev. Biol., 154: 284-298. DOI: 10.1016/0012-1606(92)90068-R

Taubes, G., 2001. The soft science of dietary fat. Science, 291: 2536-2541. DOI: 10.1126/science.291.5513.2536

Tilley, J.M.A. and R.A. Terry, 1963. A two-stage technique for the in vitro digestion of forage crops. Grass Forage Sci., 18: 104-111.

DOI: $10.1111 /$ j.1365-2494.1963.tb00335.x 
Ulbricht, T.L.V. and D.A.T. Southgate, 1991. Coronary heart disease: Seven dietary factors. Lancet, 338: 985-992. DOI: 10.1016/0140-6736(91)91846-M

Ungar, E.D. and I. Noy-Meir, 1988. Herbage intake in relation to availability and sward structure: Grazing processes and optimal foraging. J. Applied Ecol., 25: 1045-1062. DOI: $10.2307 / 2403765$

Vestergaard, M., N. Oksbjerg and P. Henckel, 2000. Influence of feeding intensity, grazing and finishing feeding on muscle fibre characteristics and meat colour of semimendinosus, longissimus dorsi and supraspinatus muscles of young bulls. Meat Sci., 54: 177-185.

DOI: $10.1016 / \mathrm{S} 0309-1740(99) 00097-2$

Wheeler, T.L., J.W. Savell and H.R. Croos, 1990. Mechanisms associated with the variation in tenderness of meat from Brahman and Hereford cattle. J. Anim. Sci., 68: 4206-4220. DOI: $10.2527 / 1990.68124206 x$

Yamamoto, S.M., F.A.F. Macedo, M. Zundt, A.A. Mexia and E.S. Sakaguti et al., 2005. Fontes de óleo vegetal na dieta de cordeiros em confinamento (Sources of vegetable oil in the diet of lambs in feedlot) (In English). Rev. Bras. Zootecn.
Young, A.O. and T.J. Braggins, 1993. Tenderness of ovine semimembranosus: Is collagen concentration or solubility the critical factor. Meat Sci., 35; 213-222. DOI: 10.1016/0309-1740(93)90051-I

Zapata, J.F., C.M. Nogueira and L.M.J. Seabra, 2003. Característcas da carne de pequenos ruminantes no Nordeste do Brasil (Characteristics of the meat os small ruminants in Northeast Brazil) (In English). Boletim Sociedade Brasileira de Ciência e Tecnologia de Alimentos.

Zundt, M., F.A.F. Macedo, J.L.L. Astolphi, A.A. Mexia and E.S. Sakaguti, 2006. Desempenho e características de carcaça de cordeiros Santa Inês confinados, filhos de ovelhas submetidas à suplementação alimentar durante a gestação (Performance and carcass characteristics of SantaInês lambs in feedlot, offspring of sheep submitted to dietary Supplementation during pregnancy) (in English). Rev. Bras. Zootecn. 